\title{
Impact of Job Design on Employees' Performance \\ (With Special Reference to School Teachers in the Kalmunai Zone)
}

\author{
Mrs. MACF. Aroosiya \\ Faculty of Agriculture \\ Eastern University, Sri Lanka \\ fathimaaroosiya@gmail.com \\ MAM. Hussain Ali \\ Department of Management \\ South Eastern University of Sri Lanka \\ hussainm@seu.ac.lk
}

\begin{abstract}
The objective of this study was to investigate the impact of job design on employees' performance in the school of Kalmunai Zone in Sri Lanka and which factors of job design highly influence on employees' performance in the organizations. To analyze this condition, one hypothesis was formulated using deductive approach. The study was conducted by using a random sample of five school in Kalmunai Zone. Type of investigation was correlational and it was cross-sectional on time horizon. The unit of analysis was organizational level; each school. Teachers served as respondents on behalf of the firm. Measures of the study were of good quality after assuring reliability and validity. Data were collected from 103 respondents which was 100\% response rate. In order to test the hypothesis that was concerned with relationship between perceived level of job design and perceived degree of employees' performance the Pearson Product-Movement Correlation technique was applied. The results of the study showed a significant and positive relationship between perceived level of job design and perceived degree of employees' performance in the schools. Found relationship was significant (correlation coefficient was .363 that was significant at 0.01 level) implying that a school should adopt an effective task identity, autonomy and feedback in order to improve teachers' performance.
\end{abstract}

\section{Keywords: Job Design, Teacher's Performance, Government Schools}

\section{Introduction}

Human Resource is the most important resource compared with other resources like machine,material, land, etc. In the organizational context, the effectiveness of human resource depends on designing the job according to human capability and characteristics. Job design is the most important function of Human Resource Management. It indicates that, designing of contents, methods, functions of a job.

The performance of an employee is that, how well an employee performs his or her task duties and responsibilities. Employees' performance is also crucial. Because the achievement of goals and objectives of the organization is assessed by performance of its resources, employees' performance should be assessed and maintained 
periodically. Teachers also one of the employees category in the education sector. Therefore, the teachers' performance also is crucial in education sector.

The education is the most important to produce a total man with the knowledge, attitudes and skills required not only for the present world but also for that of the future. In the case of delivery of quality education, the teachers are the most crucial \& valuable resource.

In recent decades the picture has changed. There has been sharp decline in the standard and quality of education at all levels. Navaratna (1999) indicated that the reading habit and the use of libraries in the learning process have almost disappeared from our education culture. Ginige (1997) emphasized that, deteriorating educational standards and rapidly growing private tuition, together with the widening gab between the schools, authorities should rethink education in terms of customer- focused new approaches to fulfill the needs of a changing society. So further he noted that, the educational authorities today are compelled to look for new strategies that can improve the quality of school system. These necessity leads to curriculum development.

The curriculum development impact teachers, students, society as well as the government. The challenges for government is that, when new curriculum is implemented, there would be a increased cost to government in the case of printing new books, preparing the new syllabus, train the teachers as well as other relevant people to implement the new curriculum. Hence, it requires high skilled and competitive people. Regarding this, government has responsibility in designing the curriculum to create highly talented people in Sri Lanka. As the government performs curriculum development the teachers' job also has to redesign to achieve the goals of new curriculum.

It is better to analyze teacher's job design \& its impact on their performance. In the view of the researchers, most of the teachers face the big problem in relation to their roles change periodically \& become more complex because of the curriculum development which includes changes in subjects, teaching methodology, evaluation and control. This changes highly impact on teachers' satisfaction and their performance. So, these issues are to be studied empirically.

There are very few studied carried out in Sri Lanka in respect of school teachers. A research carried out by Gunawardena (1991) focused on 'Teachers' Perceptions of the Organization of the School'. Another research carried out by Hettige (1997) focused on 'Finding out what Characteristics of Principals' Leadership Behavior would contribute to the Improvement of Enthusiasm and Allegiance of the TeachingStaff in Performing School Activities'. Another research done by Kudaligama (1991) focused on 'A Study of the Effects of the Group Method of Team Teaching on Student Achievement in Secondary School Classes'. These researches had not focused on job design and teachers' performance. Further a research carried out by Riyasa (2008) focused on 'Impact of Job Design on Employee's Satisfaction in Daya Garments in Ampara. She focused on job design but not teachers' performance. So it is possible to note that no prior studies were carried out on job design in relation to employee performance regarding school teachers. It seems that there is a gap in this knowledge about testing the relationship between job design and teachers' performance. This paper focuses on addressing the following research problems: 
1. Is there a significant relationship between Job Design and Employees' Performance?

2. What factors of job design contribute to proper performance of school teachers?

The objectives of the paper are to investigate whether Job Design significantly relates to Employees' Performance for School Teachers in the Kalmunai Zone; to find out the effectiveness of teachers' job design, the degree of teachers' performance, and to explain how job should be redesigned to improve job performance.

\section{Research Framework}

Job Design: In the view of Opatha (2002), 'Job design is the functions of arranging task, duties and responsibilities in to an organizational unit of work'. The working definition for the study purpose is that, 'The job design is the way to organize the contents, methods and relationship of jobs in order to achieve organizational goals and objectives as well as satisfaction of job holders. There are various approaches to job design. Regarding this Aswathappa (2006) explained that, various approaches to job design are namely; Job Rotation, Job Engineering, Job Enlargement, and Job Enrichment.

In the view of Garg \& Rastogi (2006), it is closely associated with sophisticated computer applications, Computer Assisted Design (CAD), and human - machine interactions.

Job rotation and job enlargement were designed to take advantage of specialization of labor from the job engineering approach (Luthans, 2005). Job rotation allows an employee to work in different departments or jobs in an organization to gain better insight in to operations (http://edweb.sdsu.edu/people/arossett/pie/menu. htm).Job enlargement can be used to increase motivation by giving employees more and varied task (http://edweb.sdsu.edu/people/ arossett/pie/menu.htm). Job enrichment (JE) is the technique entails enriching job, which refers to the inclusion of greater variety of work content, requiring a higher level of knowledge and skill, giving workers, autonomy and responsibility in terms of planning, directing, and controlling their own performance, and providing the opportunity for personal growth and meaningful work experience (Garg \& Rastogi, 2006). According to Herzberg (2003), job enrichment provides the opportunity for the employees' psychological growth, while job enlargement merely makes a job structurally bigger.

According to Hertzberg's theory, only a challenging job has the opportunity for achievement, recognition, advancement and growth that will motivate personnel. Because of that, job characteristics model (JCM) superseded the two-factor theory and it is the most widely recognized model (Garg \& Rastogi, 2006). The Hackman \& Oldham model suggests the relationship between five core job dimensions skill variety, task identity, task significance, autonomy and feed back - and the occurrence of intrinsic motivation (Samarakoon, 2002).

In the view of Garg \& Rastogi (2006), Skill variety refers to the extent to which the job requires the employee to draw from a number of different skills and abilities as well as upon a range of knowledge, Task identity refers to whether the job has an identifiable beginning and end or how complete a module of work the employee performs, Task significance refers the degree to which the job affects the lives or work of other people, Autonomy refers the degree to which the job provides freedom, independence, and discretion to the individual in scheduling the work and in determining the procedures, and Feedback refers the degree to which carrying out 
the work activities required by the job results in the individual's obtaining direct and clear information about the effectiveness of his or her performance.

Employees Performance: In the view of Putterill and Rohrer (1995), Job performance is defined as it focuses directly on employee productivity by assessing the number of units of acceptable quality produced by an employee in a manufacturing environment, within a specific time period.

Hence the researcher has developed the working definition for study purpose is that, achievement of targets of the tasks assigned to employees within particular period of time. The success of business depends on employees' performance. One of the most effective ways to increase business performance and profit is to increase the performance of employees, from the lowest levels of the organization to senior management (http://www.quantisoft.com/index/html).

Performance improvement is not only a result of well functioning system but also depends on effective human resource strategies that succeed in recruiting and maintaining a committed and motivated workforce (Al-Ahmadi, 2009).

The dimensions of performance on which an employee is evaluated are called the criteria of evaluation (Ivancevich, 1998). (Opatha, 2002) suggested that several criteria becomes needed in order to evaluate job performance of an employee accurately. In the view of Mathis\& Jackson (2003), the data or information that managers receive on how well employees are performing their jobs can be of three different types. Trait-based information, Behavior-based information, Result based information. Opatha (2002) indicated that trait-based information identifies a subjective character of the employee such as attitude, initiative or creativity. Behavior-based evaluations of job performance focus on what is included in the job itself (Mathis\& Jackson, 2003). Results are outcomes produced by the employee. Result based information consider employee accomplishment. For jobs in which measurement is easy and obvious, a results-based approach works well (Opatha, 2002).

There are various evident for relationship between job design and employees' performance. Al-Ahmadi (2009) indicated that the nature of job itself was found positively correlated with performance, which indicates that satisfaction with amount of variety and challenge in one' $s$ job actually influence performance. The sense of job significant, feeling important in eyes of others, realizing ones' competence, and freedom to make decisions are positively related to performance. Ivancevich (1998) suggested that, approaches to job design place different emphasize on performance and satisfaction as desired outcomes. In other words, certain methods of job design are primarily interested in improving performance; others are more concerned with satisfaction.

According to Borman, employee training and job redesigning, the focus is almost always on improving job performance (Borman, 2004 as in Kahya, 2007). Some argue that job design improves workers motivation and dedication to work however at closer examination job design can only contribute to better efficiency within an organization eliminate some health problems. But will not impact employees' morals and enthusiasm at work (http://www.customwritings. com/blog/author/admin/). In the view of Garg \& Rastogi (2006), well designed jobs can have a positive impact on both employee satisfaction and quality of performance. The perceived work demands, job control and social support through job design leads to high productivity(Love \& 
Edwards, 2005 as in Garg \& Rastogi,2006). Like wise Campion et al (2005) suggested that Nature of work has a substantial impact on an employee's performance and attitude.

These finding stated that there is a strong relationship between Job design and Employees' performance. So according to these findings the following hypothesis was developed;

H1: Perceived systematic use of job design of a firm is significantly and positively related to employees' job Performance.

Figure: 1 presents the relevant schematic diagram. Systematic design of job is labeled as the independent variable and perceived employees' performance is labeled as the dependant variable.

Figure: 1 Schematic Diagram of the Research Framework

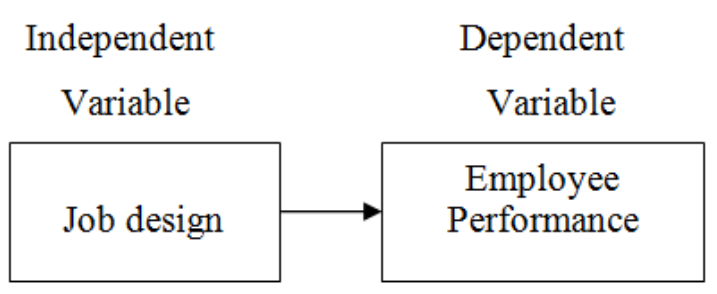

\section{Method}

\section{Study Design}

The researchers were interested in investing whether job design (JD) relates to employees' performance of school teachers. There was no intention of establishing definite cause effect relationship between the two variables. The type of investigation of this study was correlational rather than causal. Because this study attempted to analyze the relationship between the dependent variable and independent variable, this study was analytical in nature or purpose.
Study was conducted in the natural environment of the organization with direct interference by the researchers with the normal flow of work. The researchers used a questionnaire to individuals. Hence, the extent of research interference was high as this study was a field study.

Population of this research included the Schools in the Kalmunai Zone. There are 59 schools in Kalmunai Zone. Simple random Sampling method was applied and following Table gives the sample information.

Table 1 Simple Random Sampling

\begin{tabular}{|l|l|l|l|}
\hline $\begin{array}{c}\text { Selected } \\
\text { Schools }\end{array}$ & $\begin{array}{c}\text { No. of } \\
\text { Teachers }\end{array}$ & \multicolumn{1}{|c|}{$\begin{array}{c}\text { Random } \\
\text { Selection }\end{array}$} & $\begin{array}{c}\text { Random } \\
\text { Selection } \\
(25 \%)\end{array}$ \\
\hline College & $\mathrm{N}=106$ & $25 \%$ & $\mathrm{~N}=27$ \\
\hline College & $\mathrm{N}=92$ & $25 \%$ & $\mathrm{~N}=23$ \\
\hline College & $\mathrm{N}=64$ & $25 \%$ & $\mathrm{~N}=16$ \\
\hline College & $\mathrm{N}=103$ & $25 \%$ & $\mathrm{~N}=26$ \\
\hline College & $\mathrm{N}=45$ & $25 \%$ & $\mathrm{~N}=11$ \\
\hline Total & $\mathrm{N}=410$ & $25 \%$ & $\mathrm{~N}=103$ \\
\hline
\end{tabular}

(Source: Survey data)

Selected sample size for the study was 103 ( $\mathrm{n}=$ 103 ) as shown in the above table which accounts to a random selection of $25 \%$ of the population $(n=410$ Teachers) in order to make the sample more representative. The $25 \%$ sample was drawn from each selected school in the zone of Kalmunai. The sample frame selected for study from the Zonal Education office in Kalmunai. This office is providing services to the all the schools in the Kalmunai Zone

Structured questionnaire was developed and distributed among the selected teachers in the schools under the sample. It was possible to collect whole questionnaire from 5 schools in kalmunai Zone. 


\section{Measures}

Job Design: The perceived degree of job design in an organization was operationalized into five dimensions i.e., Skill Variety, Task Identity, Task Significance, Autonomy and Feed Back (Samarakoon , 2002; Garg \& Rastogi 2006; Luthans, 2005). The questionnaire assesses dimensions of job design and employee performance. dimensions of skill variety, task identity, task significance, autonomy and feedback. The questionnaire finds out the extend to which one possesses job design. The 15 question items are divided into 5 factors: skill variety, task identity, task significance, autonomy and feedback. A 5-point Likert scale is used to evaluate answers.

Employee Performance:_The perceived degree of employee past performance was operationalized into three dimensions such as traits, behaviors, and results Trait-based information, Behavior-based information, Result based information (Opatha, 2002; Duraisingam and Skinner, 2005; Mathis and Jackson, 2003). A questionnaire was developed to measure the variable of employee performance and it has 29 question items. The 29 question items were divided into three factors: traits, behaviours and results. A 5-point Likert scale was used to evaluate the answers.

\section{Techniques of Data Analysis}

There was a hypothesis of the study. It was about relationship between two variables, and hence the Pearson Product-Moment Correlation technique was used. Data was completed through directly handover questionnaire survey. Each questionnaire was carefully scrutinized and confirmed that all the questionnaires received back had been filled properly. All returned questionnaires were serially numbered and the information contained was transferred to worksheets by assigning with scores. The data analysis of this study involved two types of analyses i.e., Univariate analysis (involving one variable at a time) and Bivariate analysis (involving two variables at a time). In this study it was possible to use the mean and the standard deviation which are appropriate indicators of central tendency and dispersion because the interval scales were used as the basis of measurement. In addition, the standard deviation is an important concept for descriptive statistical because it reveals the amount of variability of individuals within the dataset.

Under the Bivariative analysis, parametric tests were used because the data were collected on interval scales and data was normally distributed. Pearson correlation coefficient was used by the researcher to reveal the strength of two variables for interval scale.

\section{Results}

The teachers' job design and their performance have been reviewed by the researcher and found that the few dimensions of job design must be improved. Based on the result of Univariative analysis, the degree of systematic quality level of each dimension of job design and teachers performance is shown in the table 2 below.

The first hypothesis formulated for the study was that perceived systematic use of Job Design is significantly and positively related to its employees' performance. The relevant null hypothesis is stated that there is no relationship between perceived systematic use of Job Design and its employees' performance. The appropriate statistical test was Pearson Correlation Coefficient in order to test alternative hypothesis. Desired level of significant level was 0.05 . One tailed test was used as the formulated alternative hypothesis 
had been directional. Following Table 3 presents the results of the correlation test.

Table 2 Results of Measurement of Job Design and Teachers Performance

\begin{tabular}{|l|l|l|l|}
\hline Variables & Mean & $\begin{array}{l}\text { Standard } \\
\text { deviation }\end{array}$ & Level \\
\hline Job design & 61.24 & 4.27 & High \\
\hline Skill variety & 13.01 & 1.54 & $\begin{array}{l}\text { Very } \\
\text { high }\end{array}$ \\
\hline Task identity & 12.52 & 1.81 & High \\
\hline Task significance & 12.88 & 1.64 & $\begin{array}{l}\text { Very } \\
\text { high }\end{array}$ \\
\hline Autonomy & 11.30 & 1.10 & High \\
\hline Feedback & 11.52 & 1.02 & High \\
\hline Teachers' performance & 119.8 & 4.75 & $\begin{array}{l}\text { High } \\
\text { level }\end{array}$ \\
\hline
\end{tabular}

(Source: Survey Data)

Table: 3 Correlation between Job Design and Employee performance

\begin{tabular}{|l|l|}
\hline Pearson correlation & $.363^{* *}$ \\
Sig. (1-tailed) & .000 \\
$\mathrm{~N}$ & 103 \\
\hline
\end{tabular}

(Source: Survey data)

According to table Pearson correlation is 0.363 suggesting that there is a positive relationship between Job Design and Employee performance. As the significant value $(0.000)$ is smaller than the desired level of significance (0.005), the found correlation coefficient (0.363) is statistically significant. Hence alternative hypothesis can be accepted while rejecting the null hypothesis. Therefore, there is statistical evidence to claim that there is a significant relationship between perceived systematic use of Job Design of a firm and its employees' performance.

\section{Discussion}

The study found empirical evidence to support the hypothesis of perceived systematic use of Job Design is significantly and positively related to its employees' performance. It is more likely that systematic use of Job Design is significantly and positively contributes to employees' performance of a firm positively and significantly. This finding empirically confirms the theoretical arguments given by Al-Ahmadi (2009), Ivancevich (1998),

(Kahya, 2007), Garg \& Rastogi (2006), Aswathappa (2006), Mathis and Jackson (2003),

Campion et al (2005), and Perry et al, (2006).They explained that strong, positive relationship exist between the extent of a firm's adoption of high involvement HRM strategies including JD and employees' performance. Implication of finding is that, should adopt a more systematic design of job in order to improve its employees' performance For the purpose of enhancing quality level of Job Design it is essential to work on all 5 dimensions, i.e., Skill Variety, Task Identity, Task Significance, Autonomy and Feed Back.

A finding derived from univariative analysis if the data was that quality level of JD in schools is high implying that it some degree of improvements are needed to reach the level of very high. The dimensions of skill variety, task significance are very high level in terms of quality. Regarding other three elements namelytask identity, feedback \& autonomy are just high level in terms of quality under the univariative analysis. An implication is that more attention has to be given to improving task identity, feedback \& autonomy so as to improve quality level of Job Design for school teachers that they can improve their employees' performance in achieving quality students. 


\section{Conclusion}

The results of the study lead to confirm the prediction made by the researchers regarding a significant and positive relationship between perceived systematic use of Job Design and perceived degree of Employees' Performance of School Teachers. It is more likely that an improvements of quality of JD for School Teachers results in improvements of Employees' Performance.

\section{Reference}

Al-Ahmadi.H, (2009), 'Factors Affecting Performance of Hospital Nurses in Riyadh Region, Saudi Arabia', International Journal of Health Care Quality Assurance, Vol. 22 No. 1, pp.40-54.

Aswathappa.K, (2006), 'Job Analysis and Job Design', Human Resource and Personal Management, $4^{\text {th }}$ Edition, pp.93-125, India: Tata McGraw-Hill Publishing Company Limited.

Campion.M.A, Mumford.T.V, Morgeson.F.P, and Nahrgang.J.D, (2005), 'Work Redesign: Eight Obstacles and Opportunities', Human Resource Management, vol. 44, no. 4, pp367390.

Duraisingam.V and Skinner. N, (2005), 'Workforce Development 'TIPS' Theory into Practice Strategies', Performance Evaluation, Alcohol Education and Rehabilitation Foundation Ltd (AER).

Garg.P \& Rastogi.R, (2006), 'New Model of Job Design: Motivating Employees' Performance', Journal of Management Development, Vol 25 no 6, pp.572-587.

Ginige.I.L.,(1997), 'Quality Improvement In Education: Planning For Implementation Of Total Quality Management(TQM) In Schools Of
Sri Lanka', SAARC Journal Of Educational Research,Vol.3 No.1, pp.13-22.

Gunawardena.C, (1991), Teachers' Perceptions of the Organization of the School: Sri Lankan Journal Of Educational Research, Vol.2 No.1, Published By Department Of Educational Research, NIE, Sri Lanka, pp.33-52.

Herzberg.F, (2003), 'One More Time: How Do You Motivate Employees', Harward Business Review, Vol-81, pp.87-96.

Hettige, (1997), 'Finding Out What Characteristics Of Principals' leadership Behavior Would Contribute To The Improvement Of Enthusiasm And Allegiance Of The Teaching-Staff In Performing School Activities', Sri Lankan Journal Of Educational Research,Vol.6 No.1, pp.72-110.

Ivancevich.J.M,(1998), 'job analysis and job design', Human Resource Management,7th edition, pp.168-195,Irwin McGraw-HILL.

Kahya.E, (2007), 'The Effect of Job characteristics and working conditions on job performance', International Journal of Industrial Ergonomics, PP(515-523).

Kudaligama.P.K.D.P, (1991), 'A Study Of The Effects Of The Group Method Of Team Teaching On Student Achievement In Secondary School Classes', Sri Lankan Journal Of Educational Research, Vol.2 No.1, Published By Department Of Educational Research, NIE, Sri lanka ,pp.79-81.

Luthans.F, (2005), 'Managing Performance through Job Design \& Goal Setting', Organizational Behavior, 10th Edition, pp.478505, MCGRAWHILL International Edition. 
Mathis.R.L and Jackson.J.H,(2003), 'Individual Performance and Retention', Human Resource Management, $10^{\text {th }}$ Edition, pp.66-99, Thomson Publication.

Navaratna.A.A,(1999), 'New Education Reforms', pp.1-61, Published Presidential Task Force On General Education In Srilanka.,Colombo-02.

Opatha.H.H.D.N.P, (2002), Performance Evaluation of Human Resource, $1^{\text {st }}$ Edition, pp.2-12,170-183, Colombo, Sri Lanka: the Author publication.

Perry.J.L, Mesch.D and Paarlberg.L, (2006), 'Motivating Employees in a New Governance Era: The Performance Paradigm Revisited', The Premier Journal of Public Administration, Vol 66, pp.4.

Putterill M. S. and Rohrer T. C, (1995), 'A causal model of employee commitment in a manufacturing setting' International Journal of Manpower, Vol. 16 No. 5/6, pp. 56-69.

Riyasa.A.R, (2008), 'Impact of job design on employee's satisfaction in Daya Garments, Unpublished Dissertation, South Eastern University of Sri Lanka.

Samarakoon. J.L, (2002), 'Job Satisfaction of Knowledge Workers and Retention Strategies in Software Development Industry of Sri Lanka', Sri Lanka Journal of Management, pp.8.

http://www.customwritings.com/blog/author/ad $\mathrm{min} /$ ), Accessed on 29/06/2009.

http://edweb.sdsu.edu/people/arossett/pie/menu. htm), Accessed on 08/04/2009.

http://www.quantisoft.com/index/html, Accessed on 30/06/2009. 